\title{
Measuring the Influence of the Commodity Market Performance over the Supply and Demand of Regional Air Travel
}

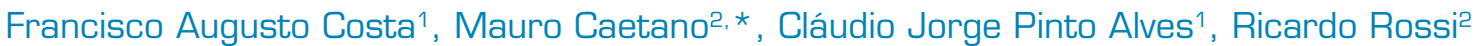

\author{
Costa FA (D) https://orcid.org/0000-0002-1375-2194 \\ Caetano M (iD) http://orcid.org/0000-0002-5978-1054 \\ Alves AJP (D) https://orcid.org/0000-0003-3451-6702 \\ Rossi R (1D) https://orcid.org/0000-0002-2198-0576
}

\section{How to cite}

Costa FA; Caetano M; Alves CJP; Rossi R (2019) Measuring the Influence of the Commodity Market Performance over the Supply and Demand of Regional Air Travel. J Aerosp Technol Manag, 11: e1219. https://doi.org/10.5028/jatm. v11.1014

\begin{abstract}
The existing relations between the supply of air transport services and economic development have been a relevant area of research in transport management. This study aims to analyze the influence of the productive performance of some Brazilian exported commodities over the demand for regional passenger air transportation on the regions where those commodities are produced. In order to do so, this study used the linear regression method, checking what the relations are, if any exist, between the productive performance of those areas and the supply and demand for passenger seats in airports located in areas producing those commodities. The mathematical model used was validated with a control model that, in its turn, examined the correlation between macroeconomic and population aggregates and the global domestic demand for passenger air travel. The results show ambiguous relations between explicative and dependent variables, because in some localities the correlation was significantly higher than in others. The main contribution is to analyze how the regional aviation market is exposed to the productive performance on markets with high level of economic specialization.
\end{abstract}

KEYWORDS: Air transport, Commodity, Regional aviation, Regional development.

\section{INTRODUCTION}

Commodities play a major role in the Brazilian economy. In 2016, Brazilian commodities with low levels of industrial processing were responsible for $42.7 \%$ of the country's exports. Soybeans, iron ore and crude oil alone totaled US\$ 42.5 billion, $23 \%$ of the US\$ 182.5 billion total Brazilian exports (MDIC 2017). Because its low aggregate value, commodities themselves are usually transported by land or water, but given the significant distance between the producing areas of those commodities and Brazil's largest cities, added to the poor quality of the Brazilian roads and the virtually inexistent passenger railway system, air transport services are essential for the integration between production sites and the economic, technologic and scientific centers of the country.

Belobaba et al. (2009) state that the air transport industry is derived from the overall economic performance. The decisions airlines make over its supply, regarding the aircraft size, the number of frequencies during a given period of time, connectivity between destinations, and the decisions governments make over the creation and maintenance of the airports infrastructure are

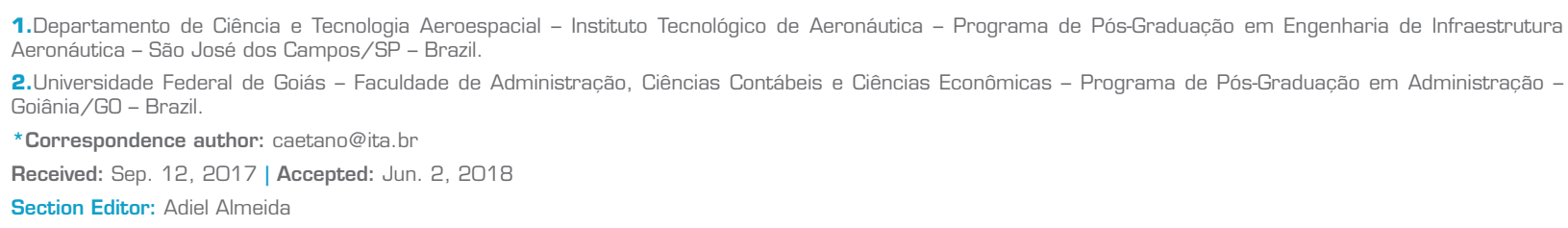


closely linked to the social and economic development of each market. One of the main areas of research of transport geography is the investigation of existing relations between infrastructure and transport services with a given region's economic development (Van de Vijver et al. 2014).

Previous studies on the impacts of macroeconomic and demographic variables over the supply and demand for air transport are valid and are able to corroborate the correlation between those factors. Belobaba et al. (2009) reveals economic interaction of city pairs, income level and age as drivers for the supply and demand, along with fares and service levels. In addition, Bettini (2007) mentions the existence of substitute services (trains or buses) as an influence to the passenger air transport markets. Factors such as GDP, exchange rates, oil prices and population over the airline business are always present on studies proposing to analyze the airline industry behavior, so those variables were researched extensively, for virtually all markets, regional air transport included.

Recently, studies of Profillidis and Botzoris (2015), Hazel (2018) and Matsumoto et al. (2016) have also analyzed the relationships between economic activity and supply and demand for air transport services on different markets around the globe. Profillidis and Botzoris (2015), conducting a research on seven different markets around the globe, and using calibrated econometric models, have found causal relations between GDP growth on those seven markets and the evolution of air transport demand leading to a plausible estimation for air transport services until 2030. Hazel (2018) analyzed a period of 20 years for the US domestic air transport services, on how capacity discipline played a major role on turning the US airline industry into a profitable business after 2008 crisis. Between another findings, one that is relevant for this study is that using GDP growth as a basis to capacity growth, airlines have managed to slightly increase its revenue per available seat mile. Matsumoto et al. (2016) presented a research that analyzes not only the role played by economic growth, but also demographic variables and trade flows as drivers for the demand of air transport services.

However, there are markets on which the concentration of a certain economic activity is so relevant to the local economy and to the local community that the performance of this activity plays a major role over the supply and demand of certain goods and services, including air transport. The role played by this given industry on the regional markets may be even more significant than other traditional drivers, such as economic and demographic ones. But the investigation on the impacts of the economic specialization of a given region over the supply and demand of the airline passenger service still lacks research.

Therefore, the study of existing relations between air transport services and economic development is relevant for policymakers, airline decisions and communities, as it allows planning and predicting a more reliable and profitable air transport service. A government will not develop airports, an airline will not create flights, and a community may end up having its airline services cut due to bad planning. Proper knowledge on how a given market reacts to economic fluctuations is significant for a reliable air transport market. On that count, the main objective of this study is to understand the influence of the commodity production performance over the supply and demand for passenger air transport services in the production areas of those commodities. As a secondary objective, the paper also intends compare if these regional aviation markets are subjected to the commodity production performance as much as the overall Brazilian domestic aviation market is subjected to more traditional economic and demographic drivers. These two objectives will be accomplished through modeling a linear regression equation that will consider, as independent variables, the production performance of four of the main commodities produced in Brazil and, as dependent variables, the supply and demand for passenger air transport services in producing areas.

As an example, one may ask if in a given region with a high level of economic specialization (say, oil drilling), the elasticity for goods and services is higher or lower when oil prices vary, when the amount of oil extract from that region varies or when national economic and demographic indexes vary? For the regional aviation market, what is more relevant, national economic performance or local economic performance? These are the discussions lacking on current literature this study intends to start. If factors driving the behavior of the market at a broader level are known, further studies should research what drives the supply and demand for passenger air transport services at a local level, especially on those markets in which the economic activity is strongly based on producing a given good.

Fernandes et al. (2014) point how previous studies on the impact of economic activity over the air transport industry usually associates GDP to the country-wide demand generation, failing to address how the economic importance of a city (called by the authors as hierarchical ranking) stimulates air transport services to that city. Also, Matsumoto et al. (2016), analyzing the volume 
of air service in East Asia, also point that economic interaction, called by the authors as business connectivity between cities acts as a driver for air transport services. This paper, then, states evidence that if a certain region has a specialized economic activity, any changes in that activity also affect air transport services to that region, to a given extent.

\section{UNDERSTANDING COMMODITIES}

Commodities are products which commerce happens in a global scale, and, because of it, supply and demand are driven by other forces than individual producers. The concept of what is a commodity must be clearly understood. Commodities are products with little or no difference on its characteristics, with a variable number of producers and no elasticity of supply and demand on the short term (Williamson 1989). According to Martins and Martinelli (2010), commodities may be agricultural, mineral, financial or even environmental.

Billon and Good (2016) explain how the price and production level of commodities affects the economic performance of producing regions of this kind of product, as it is the case of the regions from which the behavior of the supply and demand for passenger air transport are object of this study. The authors explain that, in the market, there are ambiguous expectations over the variation of the prices and of the production level of the commodities for the following years, because as those levels have been in a low for several years, there's expectations for the rise of the demand (and therefore, for the rise of prices and for the rise of production). On the other hand, the persistent slowdown of the Chinese economy and the recent history of oversupply, with high levels of inventories being held across the globe, might be able to keep those prices in a very low level, driving the production of these goods to a halt.

The impact of this erratic behavior on prices and production output of the global commodities has significant impacts for the production areas, not only because of lower sales, but new investments and, with that, generation of employment and wealth are compromised. This may lead to inflation and currency depreciation and that situation is made worse in countries suffering fiscal deficits (Billon and Good 2016). These facts show that the commodities market performance may influence other markets of which demand is derived from the overall economic performance, such as goods and services (Belobaba et al. 2009).

As an example, according to Castro (2013), the soya bean cropping in the Brazilian state of Mato Grosso led to a General Index of Socioeconomic Development (IGDSE) between 2000 and 2010, that was significantly higher in the cities in which soya was being planted, in comparison with non-planting cities. As a matter of fact, Richards et al. (2015) have concluded that the growth of soya bean plantations in Mato Grosso was the main driver of not only the state's overall economic growth, but also for the demand of services, housing and consumer goods, and providing investing capital to other economic sectors. As pointed by the authors, each $\mathrm{km}^{2}$ of soya plantation is responsible for 2.5 new jobs for non-agricultural economic activities, including the air transport services.

\section{REGIONAL AIR TRANSPORT SERVICES}

The history of the Brazilian regional aviation has been widely studied (Bettini 2007; Bettini and Oliveira 2011). After the heavy regulations of the SITAR policy (a government subsidy for regional aviation, based on a 3\% tax over the non-regional domestic airline fares) from 1975 to 1999, regional aviation services faced several changes in regulations, leading to an end in governmentprovided subsidies and to a path towards free markets.

Despite of previous studies, the proper definition of what is regional aviation and what a regional airport is, to a certain level, subjects to different views specially because there is not a legal definition of what regional aviation is, even in a strongly regulated market as Brazil (Torres et al. 2015). But there is consensus that regional aviation markets are characterized by a reduced number of flights and passenger, and by shorter routes. 
Due to the long distances from the commodity producing areas to the main economic centers of Brazil, the existence of regional airports in the producing areas and the existence of airline services to those airports pose direct impacts on the development of such regions. Also, ground travel in Brazil (whether by road or rail), is very limited due to several infrastructure constraints, similar to those presented by Halpern and Bråthen (2011). The size of the country also plays a major role on the need for regional aviation services, especially for distant, low-density markets.

Allroggen and Malina (2014) claim that the contribution of a regional airport to a local economy is related to the supply of air transport provided on that airport. In other words, if there is airport infrastructure without airline services being provided, there are no gains for the communities involved. This comprehension is relevant for this study, because as the services are rendered, given that demand is existent to some extent, it is necessary to analyze if the demand for air transport services is somehow driven by the economic specialization of the region.

Current studies show that the main drivers for the demand for air transport are, in general, social and economic aggregates such as population and expenditure, in addition to tariffs and oil prices (Baikgaki and Daw 2013). In the other hand, other studies (Torres and Portugal 2013) claim other drivers, such as airport location, other transport services and even general geographic characteristics may influence the services provided. Baker et al. (2015) found a bidirectional relationship, in both short and long runs, in which the existence of airports drives the economic regional growth, and the overall economic state drives the number of passengers on existing airports. Several different models (Ghobrial 1997; Long et al. 2001; Carson et al. 2011; Li and Trani 2014) use demographic, economic and social indexes in forecasting air transport services demand.

\section{MATERIALS AND METHODS}

This section presents the procedures and criteria used for the data collection and for the statistical modeling proposed. As stated in the introductory section, this study aims to understand the influence of the commodity production performance over the supply and demand for passenger air transport services in the production areas of those commodities. As a secondary objective, the paper also intends to compare if these regional aviation markets are subject to the commodity production performance as much as the overall Brazilian domestic aviation market is subject to more traditional economic and demographic drivers.

The main hypotheses this paper wants to verify is if when a given region experiments a significant economic specialization, variations of the level of this economic activity influence the supply and demand for air travel service. In other words, in areas with significant economic specialization, the elasticity of the supply and demand is based on the economic activity on a regional level, or is it based on the economic activity and demographic variations at a broader, national level? To test this hypothesis, this paper presents the data collected reflecting a 15-year period ranging from 2002 to 2016, and for each individual market, one yearly observation was registered for the following variables:

- Production: the volume of commodity produced on the year, in the usual market unit of that commodity (such as barrels for crude oil and gross weight for other products);

- $\quad$ Price: the average selling price, per year, of the commodity in the market;

- $\quad$ ASK (Available Seat Kilometer): the total supply (available seats) for flights departing the market in the year;

- $\quad$ RPK (Revenue Passenger Kilometer): the total demand for flights departing the market in the year, based on the product of paying passengers and distance flown. RPK is the demand a market can generate given factors such other means of transport, economic and demographic data, and others;

- Tariff level: this is a proxy variable that represents the average price of the airline service tariffs, for the market, in the year. As there is no public database for historical airline pricing for the particular markets of this study, a proxy was created from the product between average distance from departing flights of the market and the average yield of flights departing the state the market is located;

- Macroeconomic and demographic data: the variables Unemployment Rate, Total Population, GDP and GDP per capita, at a national level on a yearly base will be used in the secondary objective of the study. 
The variables mentioned above were selected according to different criteria: RPK, ASK and tariff level are recurrent explanatory variables on studies regarding the airline business, as they are also important indicators for the industry, being used, for example, on airline's investor relation reports and on civil aviation authorities' data. Price and production volume of the commodities were selected as the best variables that would represent the economic activity at a regional level, on commodity production regions, assuming a "proxy" role for what GDP means for previous studies at national and international levels. Finally, the criteria for choosing the macroeconomic and demographic data was that this kind of variables were previously used and are accepted as explainable variables on previous studies on this subject.

As the criteria to decide which regional aviation market, that has its economy strongly based on producing commodities, four relevant activities were chosen for analysis: iron mining, oil drilling, steel production and soya bean production. In line with these sectors, the airports chosen to be studied were Carajás (state of Pará), Campos dos Goytacazes (state of Rio de Janeiro), Ipatinga (state of Minas Gerais) and Sinop (state of Mato Grosso).

For iron mining, the values of production volume were extracted from official reports from Vale S/A (2016), the sole company extracting iron ore at the Carajás mountain range, being considered only the data stated on those reports as mineral production of the Sistema Norte (name given by Vale for its mining activities at the Carajás site, in northern Brazil), and the sales values are based on the international prices of iron ore. The production data are based on metric tonnes, and were found in Vale's publication Production Report (Vale S/A 2016), quarterly issued by the company. The pricing is in US dollars per metric tonne, using the CFR Tianjin Port pricing, being found at The Steel Index publication (Usiminas S/A 2016).

For steel, the values of production volume were extracted from official reports of Usiminas S/A (2016), considering only Ipatinga's steel mill (the company has other mill in Cubatão - state of São Paulo). This data is stated in metric tonnes, and the pricing is stated by the average sales value per metric tonne, in thousands of Reais (BRL) per metric tonne. Both the production and the pricing data were found in the company's reports to investors (Usiminas 2016).

For oil drilling and extraction, the values of production volume were extracted from the yearly reports of the Brazilian Oil Agency (ANP 2016), and are based on the total volume of oil extraction at the state of Rio de Janeiro, and the sales values are based on the international prices for oil barrel. The production data are based on millions of barrels and were collected straight from ANP's reports (ANP 2016). The pricing is stated on US dollars per West Texas Intermediate oil barrel, being found at the US Energy Information Administration.

For soya bean, the values of production volume were based on the metric tonne produced in Sinop and surrounding cities. This data is provided by the Brazilian Census Agency (IBGE 2017). The soya bean pricing is based on the yearly average, as stated by Chicago Board of Trade and is stated in US dollars per metric tonne.

For the macroeconomic and demographic data used for the secondary objective of the study, ipeadata (IPEA 2016) was used. Ipeadata is another Brazilian government agency, focused in economic studies. Unemployment represents the percentage of the workforce not engaged on regular economic activity, Population represents the total Brazilian population, in thousands, GDP represents the total GDP of the country in the year, in current values, in millions of BRL.

For the RPK and ASK on the cities being studied, statistics from the Brazilian civil aviation authority (ANAC 2016) were used. The distance flown and average yield per state, used in the proxy variable representing the average tariff, were based on the same database. The study results, shown in Table 1, refer to the commodities production data and supply and demand for passenger air transport in each of the studied locations.

Regarding the statistical modelling of the problem, the chosen method was the linear regression. On simple models such as the one proposed by this study, the linear regression is a straightforward technique, widely accepted for estimating relationships between variables and previously used on other studies about this subject. However, for the sake of simplicity, the model presents some limitations: it analyzes the independent variables in a ceteris paribus conditions, meaning that other factors that might be significant for both supply and demand for airline services (such as subsidies or a raise in the purchase power of a population) are not considered. 
Table 1. Commodity production levels, average tariff and supply and demand for passenger air transport in the production areas.

\begin{tabular}{|c|c|c|c|c|c|c|c|c|c|c|c|c|c|c|c|c|c|}
\hline $\begin{array}{l}\frac{ \pm}{\Phi} \\
\frac{-1}{\frac{1}{2}} \\
\frac{\pi}{\Sigma}\end{array}$ & Variable & lote & 2002 & 2003 & 2004 & 2005 & .006 & 2007 & 2008 & 2009 & 2010 & 2011 & 2012 & 2013 & 2014 & 2015 & 2016 \\
\hline \multirow{9}{*}{ 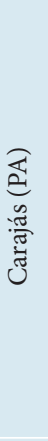 } & ASK & (a) & 14.623 & 8.612 & 8.997 & 7.403 & 7.936 & 8.519 & 8.605 & 9.813 & 40.214 & 72.564 & 98.667 & 82.274 & 105.503 & 172.079 & 147.752 \\
\hline & RPK & (b) & 7.721 & 4.491 & 4.144 & 3.510 & 3.741 & 3.646 & 3.990 & 4.405 & 20.549 & 39.735 & 61.616 & 52.812 & 72.234 & 130.994 & 107.014 \\
\hline & Load factor & (c) & $53 \%$ & $52 \%$ & $46 \%$ & $47 \%$ & $47 \%$ & $43 \%$ & $46 \%$ & $45 \%$ & $51 \%$ & $55 \%$ & $62 \%$ & $64 \%$ & $68 \%$ & $76 \%$ & $72 \%$ \\
\hline & Production & (d) & 54 & 59 & 69 & 72 & 82 & 92 & 96 & 85 & 101 & 110 & 107 & 105 & 120 & 130 & 148 \\
\hline & Price & (e) & 13 & 14 & 16 & 28 & 33 & 37 & 61 & 80 & 147 & 168 & 129 & 135 & 97 & 56 & 57 \\
\hline & Performance & (f) & 683 & 814 & 1.137 & 2.038 & 2.735 & 3.358 & 5.867 & 6.771 & 14.844 & 18.423 & 13.724 & 14.197 & 11.592 & 7.266 & 8.456 \\
\hline & Distance & (g) & 667 & 554 & 404 & 264 & 248 & 194 & 217 & 210 & 408 & 528 & 569 & 583 & 811 & 1.030 & 1.347 \\
\hline & Yield & (h) & 0.95 & 0.78 & 0.71 & 0.75 & 0.57 & 0.46 & 0.61 & 0.50 & 0.40 & 0.40 & 0.38 & 0.38 & 0.34 & 0.26 & 0.26 \\
\hline & Tariff & (i) & 634 & 430 & 288 & 197 & 141 & 89 & 133 & 104 & 165 & 213 & 218 & 219 & 277 & 268 & 350 \\
\hline \multirow{9}{*}{ 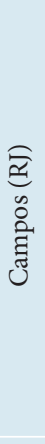 } & ASK & (a) & 1.344 & 4.960 & 3.863 & 2.604 & 1.143 & 730 & 216 & 1.948 & 2.295 & 3.797 & 7.996 & 7.125 & 11.262 & 11.109 & 8.679 \\
\hline & RPK & (b) & 489 & 1.286 & 922 & 679 & 417 & 251 & 79 & 486 & 598 & 1.390 & 4.036 & 4.540 & 7.333 & 5.440 & 3.876 \\
\hline & Load factor & (c) & $36 \%$ & $26 \%$ & $24 \%$ & $26 \%$ & $36 \%$ & $34 \%$ & $37 \%$ & $25 \%$ & $26 \%$ & $37 \%$ & $50 \%$ & $64 \%$ & $65 \%$ & $49 \%$ & $45 \%$ \\
\hline & Production ${ }^{1}$ & (j) & 438 & 446 & 443 & 502 & 530 & 521 & 547 & 605 & 595 & 569 & 561 & 532 & 563 & 597 & 639 \\
\hline & Price & (k) & 26 & 31 & 41 & 56 & 66 & 72 & 100 & 62 & 79 & 95 & 94 & 98 & 93 & 49 & 43 \\
\hline & Performance & (l) & 11.435 & 13.882 & 18.356 & 28.322 & 34.983 & 37.655 & 54.509 & 37.336 & 47.228 & 54.039 & 52.860 & 52.105 & 52.498 & 29.076 & 27.677 \\
\hline & Distance & (g) & 265 & 142 & 151 & 127 & 142 & 98 & 147 & 210 & 217 & 143 & 169 & 210 & 256 & 219 & 232 \\
\hline & Yield & (h) & 1.04 & 1.14 & 1.08 & 1.09 & 1.00 & 0.70 & 0.93 & 0.62 & 0.45 & 0.42 & 0.40 & 0.39 & 0.37 & 0.33 & 0.31 \\
\hline & Tariff & (i) & 275 & & 162 & 139 & 143 & 69 & 136 & 131 & 98 & 59 & 67 & 82 & 95 & 73 & 73 \\
\hline \multirow{9}{*}{ 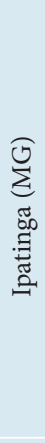 } & ASK & (a) & 21.217 & 11.248 & 18.853 & 29.804 & 31.154 & 22.638 & 21.615 & 18.067 & 29.158 & 34.344 & 49.352 & 41.473 & 22.306 & 14.520 & 15.463 \\
\hline & RPK & (b) & 9.698 & 6.568 & 10.522 & 19.372 & 17.596 & 14.111 & 13.432 & 11.032 & 18.840 & 23.802 & 31.261 & 30.959 & 17.250 & 10.634 & 10.281 \\
\hline & Load factor & (c) & $46 \%$ & $58 \%$ & $56 \%$ & $65 \%$ & $56 \%$ & $62 \%$ & $62 \%$ & $61 \%$ & $65 \%$ & $69 \%$ & $63 \%$ & $75 \%$ & $77 \%$ & $73 \%$ & $66 \%$ \\
\hline & Production & (m) & 4.575 & 4.524 & 4.738 & 4.549 & 4.616 & 4.461 & 4.269 & 2.815 & 3.935 & 3.691 & 3.852 & 3.887 & 3.450 & 2.913 & 3.126 \\
\hline & Price & (n) & 1.2 & & & 1.8 & 1.6 & 1.7 & 2.2 & 1.9 & 2.0 & 2.0 & 1.8 & 2.1 & 2.1 & 1.5 & 2.0 \\
\hline & Performance & (o) & 5.325 & 5.081 & 7.188 & 8.073 & 7.213 & 7.719 & 9.344 & 5.471 & 7.769 & 7.426 & 7.115 & 8.017 & 7.311 & 4.459 & 6.352 \\
\hline & Distance & (g) & 257 & & 260 & 257 & 258 & 190 & 178 & 190 & 224 & 236 & 241 & 277 & 199 & 157 & 157 \\
\hline & Yield & (h) & 1.16 & 1.24 & 1.17 & 1.24 & 1.15 & 0.84 & 1.34 & 0.89 & 0.49 & 0.42 & 0.44 & 0.47 & 0.47 & 0.40 & 0.42 \\
\hline & Tariff & (i) & & & & 319 & & & 239 & 169 & 110 & 99 & 106 & 130 & 93 & 63 & 66 \\
\hline \multirow{9}{*}{ 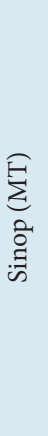 } & ASK & (a) & 4.446 & 7.270 & 7.312 & 11.059 & 9.931 & 10.653 & 12.464 & 18.745 & 24.680 & 38.017 & 49.704 & 60.157 & 74.937 & 118.398 & 87.773 \\
\hline & RPK & (b) & 2.250 & 4.562 & 4.720 & 5.365 & 5.685 & 6.222 & 6.917 & 11.722 & 14.699 & 26.530 & 34.352 & 42.258 & 52.623 & 94.580 & 67.369 \\
\hline & Load factor & (c) & $51 \%$ & $63 \%$ & $65 \%$ & $49 \%$ & $57 \%$ & $58 \%$ & $55 \%$ & $63 \%$ & $60 \%$ & $70 \%$ & $69 \%$ & $70 \%$ & $70 \%$ & $80 \%$ & $77 \%$ \\
\hline & Production $^{2}$ & (p) & 257 & 359 & 639 & 1.032 & 961 & 798 & 974 & 1.173 & 1.225 & 1.393 & 1.582 & 1.784 & 1.976 & 2.138 & 2.379 \\
\hline & Price & (q) & 201 & 233 & 277 & 223 & 217 & 317 & 453 & 379 & 385 & 484 & 538 & 517 & 458 & 347 & 363 \\
\hline & Performance & (r) & 52 & 84 & 177 & 230 & 209 & 253 & 441 & 444 & 472 & 674 & 851 & 923 & 905 & 743 & 863 \\
\hline & Distance & (g) & 498 & 502 & 485 & 1.244 & 929 & 625 & 571 & 905 & 1.025 & 1.320 & 1.429 & 1.451 & 1.608 & 1.831 & 1.694 \\
\hline & Yield & (h) & 0.90 & 1.08 & 0.80 & 0.64 & 0.49 & 0.39 & 0.59 & 0.51 & 0.39 & 0.37 & 0.40 & 0.36 & 0.35 & 0.31 & 0.35 \\
\hline & Tariff & (i) & 448 & 543 & 388 & 796 & 455 & 244 & 337 & 462 & 400 & 488 & 572 & 522 & 563 & 568 & 593 \\
\hline
\end{tabular}

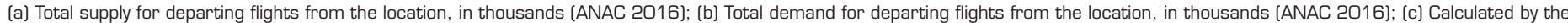

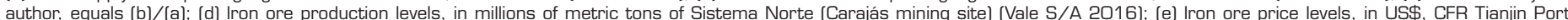

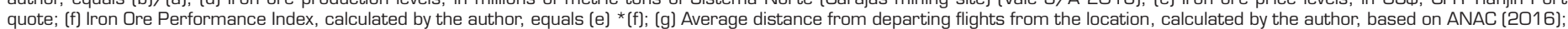

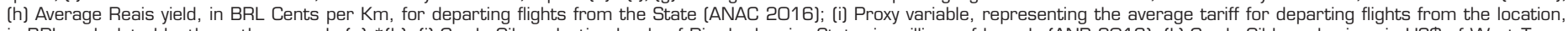

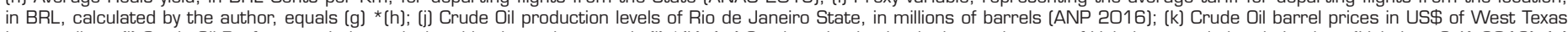

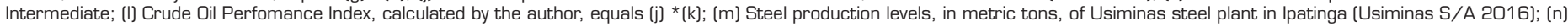

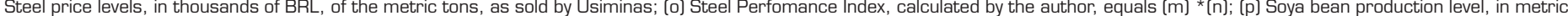

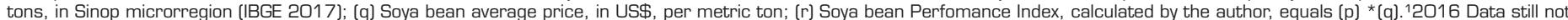

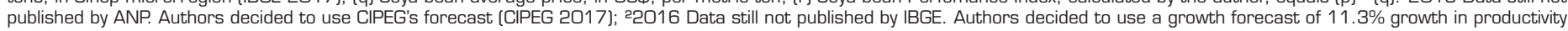
from previous year, in the State of Mato Grosso (IMEA 2017). 
The supply, demand, demographic and economic data shown in Table 2 were used as control technique in order to validate the linear regression analysis as a proper method intended for this study, and also to provide a comparison between local, commodityproducing markets, and the overall Brazilian domestic market.

Table 2. Air transport services supply and demand in the Brazilian domestic market and economic and demographic aggregates.

\begin{tabular}{|c|c|c|c|c|c|c|c|}
\hline Year & $\begin{array}{l}\text { ASK } \\
\text { (a] }\end{array}$ & $\begin{array}{l}\text { RPK } \\
\text { [a] }\end{array}$ & $\begin{array}{l}\text { Load factor } \\
\text { (b) }\end{array}$ & $\begin{array}{l}\text { Unemployment rate [\%] } \\
\text { [c] }\end{array}$ & $\begin{array}{l}\text { Total population } \\
\text { [d] }\end{array}$ & $\begin{array}{l}\text { GDP } \\
\text { [e] }\end{array}$ & $\begin{array}{l}\text { PPC } \\
\text { (f] }\end{array}$ \\
\hline 2002 & 48.872 & 27.681 & 0.57 & 11.66 & 176.304 & 1.489 & 8.444 \\
\hline 2003 & 43.345 & 26.027 & 0.60 & 12.33 & 178.741 & 1.718 & 9.611 \\
\hline 2004 & 44.900 & 29.148 & 0.65 & 11.48 & 181.106 & 1.958 & 10.810 \\
\hline 2005 & 51.214 & 35.549 & 0.69 & 10.21 & 183.383 & 2.171 & 11.836 \\
\hline 2006 & 57.248 & 40.566 & 0.71 & 9.23 & 185.564 & 2.409 & 12.984 \\
\hline 2007 & 67.479 & 45.750 & 0.68 & 8.93 & 187.642 & 2.720 & 14.497 \\
\hline 2008 & 75.377 & 49.714 & 0.66 & 7.79 & 189.613 & 3.110 & 16.401 \\
\hline 2009 & 86.325 & 56.863 & 0.66 & 9.05 & 191.481 & 3.333 & 17.407 \\
\hline 2010 & 102.731 & 70.279 & 0.68 & 9.05 & 193.253 & 3.886 & 20.108 \\
\hline 2011 & 116.096 & 81.462 & 0.70 & 7.29 & 194.933 & 4.374 & 22.437 \\
\hline 2012 & 119.338 & 87.047 & 0.73 & 6.73 & 196.526 & 4.806 & 24.454 \\
\hline 2013 & 115.907 & 88.244 & 0.76 & 7.15 & 198.043 & 5.316 & 26.845 \\
\hline 2014 & 117.053 & 93.333 & 0.80 & 7.54 & 199.492 & 5.687 & 28.392 \\
\hline 2015 & 118.231 & 94.381 & 0.80 & 9.00 & 200.882 & 5.904 & 29.392 \\
\hline $2016^{12}$ & 110.251 & 88.355 & 0.80 & 11.26 & 202.219 & 6.215 & 30.734 \\
\hline
\end{tabular}

(a) Gross value, in millions, domestic flights (regular and charter) (ANAC 2016); (b) Calculated by the author; (c) \% of unemployed (IPEA 2016); (d) Total population, in thousands (IBGE 2008); (e) GDP in current values, BRL Millions (IBGE 2015); (f) Individual GDP, estimated by the author, equals (e)/(d). 1 2016 RPK and ASK Data still not published by ANAC. Authors decided to use ABEAR's data (ABEAR 2018); ${ }^{2} 2016$ Unemployment data still not published by ipeadata. Authors decided to use PNAD's data (IBGE 2016).

\section{THEORY AND CALCULATION}

The data analysis technique used on this study was the linear regression with two (regional markets) or three (control technique) independent variables. For the regional markets, the independent variables were the production volume of the commodity and its price, and for the domestic market (control technique), the independent variables were per capita income, total population and employment. The dependent variables, for both regional and domestic markets, were ASK and RPK. The linear regression analysis shows the existing relations between independent and dependent variables, allowing the study not only of cause and effect relations, but also allowing for future estimates (Uyanik and Güler 2013).

In other words, the linear regression allows to understand the relations between dependent and independent variables and to estimate the values of the variable dependents (if those are not previously known), allowing also to identify external factors influencing those relations (Schneider et al. 2010). Alternative methods to the linear regression, however, should be applied if nonlinear relations exist between the variables.

On this study, the selected dependent variables were RPK and ASK. The selected independent variables were, for the commodity producing areas, the production volume and the sales price, and for the domestic market, the employment rate, the population and the individual income level. Therefore, the generic model used on this study are presented in Eq. 1.

$$
Y=\beta_{0}+\beta_{1} x_{1}+\beta_{2} x_{2}+\beta_{3} x_{3}+\varepsilon
$$


According to Uyanik and Güler (2013), the components of Eq. 1 are $Y$, as dependent variable (ASK or RPK) and $x_{1}, x_{2}, x_{3}$ (production volume and prices for the commodity production areas and population, employment and individual income level for the domestic market). $\beta_{0}$ is the value of $Y$ when independent variables equal zero (that is, the part of RPK and ASK driven by other factors than the studied variables), $\beta_{1}, \beta_{2}, \beta_{3}$ are the regression coefficients (change in $Y$ caused by changes in $x_{1}, x_{2}$ and $x_{3}$ ), and $\varepsilon$ is the forecast error.

\section{RESULTS}

According to Table 1, it is possible to verify a consistent growth on both production and price levels for almost all markets until the year of 2016, on which a significant fall of demand can be observed from 2015. This demand retraction (18\% in Carajás and 28\% in Campos and Sinop) is partially in line with the 7\% retraction in the Brazilian domestic market (as seen from Table 2), and reflects both the economic situation of the country and the declining tendency of the commodity performance after 2012 . Ipatinga is the location on which the market retraction is most notable, given the fact that the demand in 2016 represents $33 \%$ from the demand in 2012.

From 2002 to 2016, Carajás experienced a growth of almost $1400 \%$ of the demand, following the growth of $170 \%$ on production volume and of $350 \%$ on price levels of the iron ore. A growth of $46 \%$ on production levels and of $66 \%$ on oil prices, along with the extensive research on the pre-salt layers in the Brazilian coast were the main drivers for a 700\% growth in demand at Campos. Demand at Sinop was also marked by a significant growth, of almost $3000 \%$ following a growth of $825 \%$ on production levels and a growth of $81 \%$ in soya prices.

As can be seen from the data at Table 1, three of the four local markets studied were marked by a consistent demand growth, ranging from $700 \%$ to $2900 \%$. Growth in supply followed growth in demand by a slightly lower pace, allowing load factors to increase. For comparison purposes, in the same period, overall growth of the Brazilian domestic market was of 219\% (Table 2). Table 1 also shows a significant growth on the supply, ASK, accompanied by growth in the demand, RPK, also revealing growth in the load factors, which is a major player in the viability of regional aviation services.

According to the Table 2, between 2002 and 2016, the domestic air transport industry went through a growth of 126\% on the supply and of $219 \%$ on the demand, a fact that can be partially explained by the population growth, by the wealth distribution in terms of individual income and by the greater competition within the sector. This gap between the growth and supply and demand was responsible for a significant increase in the average load factors, from 57\% in 2002 to $80 \%$ in 2016.

Despite the confidence between the numbers shown in Tables 1 and 2 and the literature, a mathematical analysis is necessary to better verify the correlation between dependent and independent variables. A linear regression was applied, having both supply and demand as dependent variables in every studied location.

According to the results shown in Table 3, the coefficient of determination $\left(\mathrm{R}^{2}\right)$ of each independent variable was different between the four locations, as so it was the F-Significance value, which is used to check the overall significance of the regression.

Table 3. Summary of the regression analysis statistics.

\begin{tabular}{|c|c|c|c|c|c|c|c|c|c|c|}
\hline & \multicolumn{2}{|c|}{ SBCJ } & \multicolumn{2}{|c|}{ SBCP } & \multicolumn{2}{|c|}{ SBIP } & \multicolumn{2}{|c|}{ SWSI } & \multicolumn{2}{|c|}{ Brazil } \\
\hline & Supply & Demand & Supply & Demand & Supply & Demand & Supply & Demand & Supply & Demand \\
\hline Average load factor & \multicolumn{2}{|c|}{$65 \%$} & \multicolumn{2}{|c|}{$50 \%$} & \multicolumn{2}{|c|}{$66 \%$} & \multicolumn{2}{|c|}{$70 \%$} & \multicolumn{2}{|c|}{$72 \%$} \\
\hline $\mathrm{R}^{2}$ & 0.69 & 0.63 & 0.67 & 0.58 & 0.90 & 0.88 & 0.80 & 0.77 & 1.00 & 1.00 \\
\hline F-Significance & $1.2 \%$ & $2.3 \%$ & $2.7 \%$ & $5.5 \%$ & $0.0 \%$ & $0.0 \%$ & $0.8 \%$ & $0.8 \%$ & $0.0 \%$ & $0.0 \%$ \\
\hline
\end{tabular}

Data presented in Table 3 show that the value of $\mathrm{R}^{2}$ was above 0.75 only in Sinop and Ipatinga, for both supply and demand. In Campos and Carajás the higher $\mathrm{R}^{2}$ was 0.69 and 0.67 for the supply, and 0.63 and 0.58 for the demand. Based on those values, 
the model used on this study is partially able to explain the variations on both supply and demand in the four localities and shows a stronger relation between the dependent variables, ASK and RPK, and the independent variables presented on Table 1, in Sinop and specially on Ipatinga, than in Campos or Carajás. The value of F-Significance, being less than 1\% only in Sinop and Ipatinga, corroborates the statement.

The difference between the results mentioned is probably caused by different factors. The existence of another airports near Campos (Macaé, state of Rio de Janeiro, distant $110 \mathrm{~km}$ ) and near Carajás (Marabá, state of Pará, distant $120 \mathrm{~km}$ ), creating competition between those airports, may lead to changes in the dependent variables not related to changes in the independent variables. Also, an economic diversification of the regions may explain this difference, because this fact causes the supply and demand to be less affected by economic changes in the commodities market.

A third factor leading to the different results mentioned in the prior paragraph is stated by Bettini and Oliveira (2011), that explain the importance of density economics for the airline industry, especially as markets with similar characteristics of Campos: on a short route, flown by smaller aircraft (up to 70 seats) and the generation of density economics is limited, a fact that can be confirmed by the low correlation index between the ASK and the commodity production level in the region, specially until 2011.

Another factor that might explain those differences is the existence of alternative transport services, making the demand more susceptible to price changes (Kopsch 2012). Finally, when considering business travelers aiming to attend meetings personally, the demand for air transport services is driven at different levels, following the different types of economic activities (Cristea 2011). The significant growth on demand at certain markets well above the growth in the whole domestic market is remarkable and this fact, by itself, deserves further studies.

It is also necessary to revisit the commodity concept, since the regions that produce these kinds of goods are characterized by a high level of economic specialization (IMF 2015). Since the airline service derives from the economic activity, mathematic models considering only national level economic and demographic data, in other words, disregarding regional level economic specialization, may not properly reflect the behavior of derived economic activities, especially in commodity producing areas. The regional aviation market is considered in one hand as inducer of economic development, and in the other hand as dependent of scale and density economics, which are often lacking in smaller markets (Bettini and Oliveira 2011).

Therefore, even with the economic specialization of the commodities production areas, that makes its local economic performance linked to the production levels of those products, the results show the supply and demand for passenger air transport are also influenced by factors not linked to the production of such goods. Analyzing the results shown in Tables 1 and 2, it is possible to conclude that the correlation level between the commodity production performance and air transport performance, in the studied markets, even being different, exist and are positive. These findings provide a positive answer to the hypotheses formulated in the materials and methods section.

This conclusion matches the results found by Torres et al. (2015), whose study found a high number of drivers of supply and demand for air transport services, meaning that the decision to provide (by airlines) and to use (by consumers) the service is affected by several factors. The study of Baikgaki and Daw (2013) also points for factors such as household income and the average price level of the air ticket, to significantly influence the regional aviation services. The study of Fernandes et al. (2014), which analyzed Brazilian cities hierarchy as driver for airport development, also partially matches the findings of this paper, the difference being mainly to the reasons stated in the previous paragraphs, such as the elasticity of the demand to different drivers. All those independent variables considered by Torres et al. (2015) and Baikgaki and Daw (2013), which were not considered in this study, present a future opportunity to enhance the model proposed here.

\section{CONCLUSIONS}

The proper sizing of the supply and forecasting of demand, for any kind of service, are closely linked to the economic performance of a certain market even at the national level. In the airline industry, characterized by a demand which is derived from economic 
and demographic aggregates, the study of factors driving the supply and demand are even more relevant, because of the greater exposition to variables such as currency exchange or oil prices, over which economic agents have no control.

This paper presented evidence that the main drivers of supply and demand for passenger air transport in local markets differ between those markets, mainly because the weight of the economic specialization of the cities served by those airports over the services also differ. While the study presents some possible explanations, such as the existence of other airports, the different levels of economic specialization in each of those markets and the presence of different levels of density economics in each market, not all possible drivers were considered. Therefore, future research should develop a model containing other possible independent variables.

Evidence in this paper also shows that the shrinking or growth of local markets can happen at a very different rate than the rate of the overall domestic market. Therefore, the existence of local markets characterized by a high level economic specialization, not only in Brazil, also present an opportunity to further research on several of those markets and its behavior.

\section{AUTHOR'S CONTRIBUTION}

Conceptualization, Costa FA; Methodology, Costa FA and Caetano M; Investigation, Costa FA, Caetano M, Alves CJP and Rossi R; Writing, Costa FA and Caetano M; Writing and Review, Caetano M, Alves CJP and Rossi R; Funding Acquisition, Caetano $\mathrm{M}$ and Alves CJP;; Supervision, Caetano M and Alves CJP.

\section{FUNDING}

National Council for Scientific and Technological Development (CNPQ)

Grant No: 160348/2015-3, PDJ

\section{REFERENCES}

[ABEAR] Associação Brasileira das Empresas Aéreas (2018) Dados e fatos. ABEAR; [access 2017 September 1]. http://www.abear.com. $\mathrm{br} /$ dados-e-fatos/page/page:1 \#listagemquadrimestre

[ANAC] Agência Nacional de Aviação Civil (2016) Base de dados estatísticos do transporte aéreo (2005-2015). ANAC; [access 2017 September 1]. http://www.anac.gov.br/assuntos/setor-regulado/empresas/envio-de-informacoes/base-de-dados-estatisticos-do-transporte-aereo

[ANP] Agência Nacional do Petróleo, Gás Natural e Biocombustíveis (2016) Anuário estatístico do petróleo, gás natural e biocombustiveis 2016. ANP; [access 2017 June 1]. http://www.anp.gov.br/publicacoes/anuario-estatistico/2441-anuario-estatistico-2016

Allroggen F, Malina R (2014) Do the regional growth effects of air differ among airports? Journal of Air Transport Management 37:1-4. https://doi.org/10.1016/i.jairtraman.2013.11.007

Baikgaki OA, Daw OA (2013) The determinants of domestic air passenger demand in the Republic of South Africa. Mediterranean Journal of Social Sciences 4(13):389-396. https://doi.org/10.5901/mjss.2013.v4n13p389

Baker D, Merkert R, Kamruzzaman M (2015) Regional aviation and economic growth: cointegration and causality analysis in Australia. Journal of Transport Geography 43:140-150. https://doi.org/10.1016/i.jtrangeo.2015.02.001

Belobaba P, Odoni A, Banrhart C (2009) The global airline industry. Chichester: Wiley Publishing

Bettini HFAJ (2007) Um retrato da aviação regional no Brasil. Revista de Literatura de Transportes 1:46-65.

Bettini HFAJ, Oliveira AVM (2011) Transporte aéreo regional: entre economias de densidade e custos de transação. Revista de Literatura de Transportes 5(4):171-187

Billon P, Good E (2016) Responding to the commodity bust: downturns, policies and poverty in extractive sector dependent countries. The Extractive Industries and Society 3(1):204-216. https://doi.org/10.1016/i.exis.2015.12.004 
Carson RT, Cenesizoglu T, Parker R (2011) Forecasting (aggregate) demand for US commercial air travel. International Journal of Forecasting 27(3):923-941. https://doi.org/10.1016/j.ijforecast.2010.02.010

Castro LS (2013) Perfil de desenvolvimento dos municípios mato-grossenses: uma análise comparativa entre os que plantaram e não plantaram soja (2000 e 2010) (Master's Dissertation). Viçosa: Universidade Federal de Viçosa. In Portuguese.

[CIPEG] Centro de Informações da Produção de Petróleo e Gás (2017) Boletim informativo do $2^{\circ}$ quadrimestre de 2016. CIPEG; [access 2017 May 31]. http://www.petroleo.ri.gov.br/index.php/menuservicos/download/category/24-boletins-informativos

Cristea AD (2011) Buyer-seller relationships in international trade: evidence from U.S. States' exports and business-class travel. Journal of International Economics 84(2):207-220. https://doi.org/10.1016/j.jinteco.2011.02.003

Fernandes E, Pacheco RR, Braga ME (2014) Brazilian airport economics from a geographical perspective. Journal of Transport Geography 34:71-77. https://doi.org/10.1016/i.jtrangeo.2013.11.003

Ghobrial A (1997) A model to forecast aircraft operations at general aviation airports. Journal of Advanced Transportation 31(3):311-323. https://doi.org/10.1002/atr.5670310306

Halpern N, Bråthen S (2011) Impact of airports on regional accessibility and social development. Journal of Transport Geography 19(6):1145-1154. https://doi.org/10.1016/i.jtrangeo.2010.11.006

Hazel R (2018) Airline capacity discipline in the U.S. domestic market. Journal of Air Transport Management 66:76-86. https://doi. org/10.1016/i.jairtraman.2017.10.009

[IBGE] Instituto Brasileiro de Geografia e Estatística (2017) Produção Agrícola Municipal - Tabela 1612. SIDRA; [access 2017 September 1]. https://sidra.ibge.gov.br/tabela/1612

[IBGE] Insituto Brasileiro de Geografia e Estatística (2015) Produto Interno Bruto - Valores correntes. IBGE; [access 2017 September 1]. https://seriesestatisticas. ibge.gov.br/series. aspx?t=produto-interno-bruto\&vcodigo=SCN52

[IBGE] Insituto Brasileiro de Geografia e Estatística (2008) Revisão 2008 - Projeção da população do Brasil. IBGE; [access 2017 May 4]. https://seriesestatisticas.ibge.gov.br/series. aspx?vcodigo=POP300

[IMEA] Instituto Mato-Grossense de Economia Agropecuária (2017) 6 Boletim Informativo da Estimativa de Safra de Soja 2016/17. IMEA; [access 2017 May 31] http://www. imea.com.br/upload/publicacoes/arquivos/06112017183627.pdf

[IPEA] Instituto de Pesquisa Econômica Aplicada (2016) Taxa de desemprego - mensal de 2002.3 até 2015.12. Ipea data; [access 2017 May 4]. http://www.ipeadata.gov.br/exibeserie.aspx?serid=38401

[IMF] International Monetary Fund (2015) World economic outlook: adjusting to lower commodity prices. Washington: IMF.

Kopsck F (2012) A demand for domestic air travel in Sweden. Journal of Air Transport Management 20:46-48. https://doi.org/10.1016/j. jairtraman.2011.11.006

Li T, Trani AA (2014) A model to forecast airport-level General Aviation demand. Journal of Air Transport Management 40:192-206. https://doi.org/10.1016/j.jairtraman.2014.07.003

Long D, Lee D, Johnson J, Kostiuk P (2001) A Small Aircraft Transportation System (SATS) Demand Model. (Technical Report). Logistics Management Institute.

Martins TM, Martinelli DP (2010) Ciclos e previsão cíclica dos preços das commodities: um modelo de indicador antecedente para a commodity açúcar. Revista de Administração Contabilidade e Economia da FUNDACE 1(2):1-12. https://doi.org/10.13059/racef. v1i2.22

Matsumoto H, Domae K, O'Connor K (2016) Business Connectivity, air transport and the urban hierarchy: a case study in east Asia. Journal of Transport Geography 54:132-139. https://doi.org/10.1016/i.jtrangeo.2016.05.005

[MDIC] Ministério da Indústria, Comércio Exterior e Serviços (2017) Balança comercial: janeiro-dezembro 2016. MDIC; [access 2017 September 1]. http://www.mdic. gov.br/comercio-exterior/exportacao/2-uncategorised/2205-balanca-comercial-janeiro-dezembro-2016

Profillidis V, Botzoris G (2015) Air passenger transport and economic activity. Journal of Air Transport Management 49:23-27. https:// doi.org/10.1016/i.jairtraman.2015.07.002

Richards P, Pellegrina H, VanWey L, Spera S (2015) Soybean development: the impact of a decade of agricultural change on urban and economic growth in Mato Grosso, Brazil. Plos One 10(4):e0122510. https://doi.org/10.1371/journal.pone.0122510

Schneider A, Hommel G, Blettner M (2010) Linear regression analysis: part 14 of a series on evaluation of scientific publications. Deutsches Ärzteblatt International 107(44):776-782. https://doi.org/10.3238/arztebl.2010.0776

Torres RR, Portugal LS (2013) Caracterização de aeroportos regionais: contribuição para uma classificação brasileira. Presented at: XXVII Congresso Anual da Associação Nacional de Pesquisa e Ensino em Transportes; Belém, Brazil.

Torres RR, Portugal LS, Santos MPS (2015) Aeroportos regionais: organização dos indicadores do potencial de geração e atração de demanda em municípios. Presented at: XXIX Congresso Nacional de Pesquisa em Transporte da ANPET; Ouro Preto, Brazil. 
Usiminas S/A (2016) Apresentações dos relatórios trimestrais (2005-2015). Usiminas; [access 2017 June 3]. http://ri.usiminas.com/ ptb/central-de-downloads

Uyanik GK, Güler N (2013) A study on multiple linear regression analysis. Procedia - Social and Behavioral Sciences 106:234-240. https://doi.org/10.1016/j.sbspro.2013.12.027

Vale S/A (2016) Relatório de produção da companhia (2005-2015). Vale; [access 2017 June 7]. http://www.vale.com/brasil/PT/ investors/services-investor/download-enter/Paginas/default.aspx

Van De Vijver, E.; Derudder, B. Witlox, F (2014) Exploring causality in trade and air passenger travel relationships: the case of Asia-Pacific, 1980-2010. Journal of Transport Geography 34:142-150. https://doi.org/10.1016/j.jtrangeo.2013.12.001

Williamson J (1983) Open economy and the world economy: a textbook in international economics. New York: Basic Books. 